\title{
A linear sequence to facilitate curation of herbarium specimens of Annonaceae
}

\author{
Lars W. Chatrou ${ }^{1}$, lan M. Turner ${ }^{2,3}$, Bente B. Klitgaard ${ }^{4}$, Paul J. M. Maas ${ }^{5}$ \& Timothy M. A. Utteridge ${ }^{4}$
}

Summary. This paper provides a linear sequence of four subfamilies, 15 tribes and 106 genera of the magnoliid family Annonaceae, based on state-of-the-art and stable phylogenetic relationships. The linear sequence facilitates the organisation of Annonaceae herbarium specimens.

Key Words. Annonaceae, classification, herbaria, phylogenetic hypotheses, systematics, taxonomy.

\section{Introduction}

Plant taxonomy is a scientific expression for one of the defining characteristics of the human species: observing, assembling and classifying. The ordering of the plant world has been attempted ever since the origin of modern man, and even before. Neanderthals were able to distinguish fruit, nuts, roots, bulbs and tubers that were exploited as food resources (Henry et al. 2011), and upper palaeolithic hunter-gatherers recognised and categorised plants for economic and ritual uses (Nadel et al. 2013; Power et al. 2014). From Theophrastus onwards, in the fourth century BC, botanists have attempted to organise plants into classification systems. The sexual system published by Linnaeus (1753) in his Systema Naturae is the classical example of a classification system that has been designed for convenience, most notably to facilitate plant recognition and identification, and unequivocal communication about plants.

In Linnaeus's time the practice of drying and conserving plants for future study was well established. In the first half of the $16^{\text {th }}$ century, the Bolognese botanist Luca Ghini introduced a new way of studying plants by making the earliest hortus siccus. By pressing plants and storing them in a book, he invented the herbarium. It is in this era that botanic gardens, illustrated botanical publications, and herbaria were established as a trinity of resources for botanical sciences, a foundation that is still fundamental to botanical research today.
Botany in the eighteenth and nineteenth century to a large extent involved the rejection of Linnaeus' artificial system, replacing it with classifications that reflected supposed evolutionary relationships based on careful observations of plant characters. This endeavour was greatly facilitated by collections that arrived in Europe from all over the world and were kept in newly established flourishing herbaria. Up to that point, private ownership of plant collections had been common practice. In the $\operatorname{mid}-19^{\text {th }}$ century, however, these collections were often sold to the burgeoning herbaria, with the specific goal of making the collections available for study by staff and visitors. Until then, classifications such as those by Linnaeus and de Jussieu (1789) had primarily been based on European temperate plants. The influx of samples representing the wide plant diversity in colonial territories challenged these classification systems, with many non-temperate plant groups such as Annonaceae that were largely unknown to European botanists. Proliferating collections and botanical studies resulted in natural classifications by, e.g., Bentham \& Hooker (1862 1883) and Engler \& Gilg (1924), which have been the basis for taxonomic literature and for the arrangement of herbaria and botanic gardens for a long time. Given the Herculean task of changing the classification system followed in any sizeable herbarium (e.g. Wearn et al. 2013; Le Bras et al. 2017), many herbaria are still organised to date on

Accepted for publication 19 June 2018. Published online 14 August 2018

1 Wageningen University and Research, Biosystematics group, Droevendaalsesteeg 1, 6708 PB, Wageningen, The Netherlands. e-mail: lars.chatrou@wur.nl

2 Singapore Botanical Liaison Officer, Royal Botanic Gardens, Kew, Richmond, Surrey, TW9 3AB, UK.

3 Herbarium, Singapore Botanic Gardens, National Parks Board, 1 Cluny Road, Singapore, 259569, Singapore. e-mail: i.turner@kew.org

4 Royal Botanic Gardens, Kew, Richmond, Surrey, TW9 3AB, UK.

5 Naturalis Biodiversity Center, Section Botany, P.O. Box 9517, 2300, RA, Leiden, The Netherlands.

Ian M. Turner is the corresponding author. 
the basis of outmoded classification systems going back in time a century or more.

Over the past two decades or so, phylogenetic systematics has resulted in a notable transformation of the classification of plants, and of angiosperms in particular. Based on the results of phylogenetic analyses, initially the delineation of angiosperm orders and families was evaluated and changed if necessary to make plant families comply with the prime guiding criterion of monophyly (APG I 1998; APG II 2003; APG III 2009; APG IV 2016). Subsequently, working groups of systematists have applied the results of phylogenetic analyses to revise infrafamilial classifications (e.g. Schneider et al. 2014; Bone et al. 2015; Chacón et al. 2016; Claudel et al. 2017; De Faria et al. 2017; Simões \& Staples 2017), an endeavour that is still ongoing. Systematists have spent great effort in revising the classification of angiosperms because of the awareness that phylogenetics has brought methodological rigour to systematics and predictivity to classifications, which enabled the treatment of phylogenetic relationships - and therefore of classifications - as testable hypotheses, rather than opinions of scientists, however scholarly they might be.

Recently, the herbarium of the Royal Botanic Gardens, Kew, was reorganised following the APG III system at the family level and taking phylogenetic classifications into account at the infrafamiliar level. Linear sequences of plant taxa enable curators to curate herbarium collections in accordance with phylogenetic relationships among genera. Linear sequences reflect the order of names attached to the tips of a phylogenetic tree, after the branches in the tree have been ordered according to some projection method. Alternatively, herbarium collections may be organised alphabetically, and the choice between an arrangement based on alphabet or on classification has been cause for debate (Funk 2003; Burger 2004). Storing collections according to any organising system remains indispensable as herbaria have retained their historic functions, being the basis for plant systematics and taxonomy, floristics and identification, assessment of botanical diversity, and teaching. In addition, scientific developments have unlocked new applications of herbarium collections, such as the characterisation of phenological responses to climate change (Willis et al. 2017), the assessment of global rarity of plant species to guide conservation (bioquality; Marshall et al. 2016), the sequencing of near-complete plastomes (Bakker et al. 2016; Hoekstra et al. 2017) and the targeted enrichment of nuclear genes (Hart et al. 2016), both for phylogenetic and evolutionary studies.

In this paper, we present a linear sequence of genera of Annonaceae. Generally, the family is among the most species-rich and abundant families in tropical rain forest communities (e.g. Cardoso et al. 2017; Sosef et al. 2017; Turner in press) and is amply represented in major herbaria.

\section{Linear sequences}

Haston et al. (2007, 2009) published a simple methodology for translating tree-like relationships into a linear sequence, and applied this to a phylogenetic tree of angiosperm families. Similarly, linear sequences have been produced for gymnosperms (Christenhusz et al. 2011a) and lycophytes and ferns (Christenhusz et al. 2011b). In order to extend the phylogenetic arrangement of collections to the level of genera, linear sequences that translate family phylogenies are indispensable. So far, linear sequences are available for Fabaceae (Lewis et al. 2013), and monocots excluding Poaceae and Orchidaceae (Trias-Blasi et al. 2015).

The assembly of the phylogenetic tree underpinning the linear sequence, and the translation of the tree into the sequence consisted of the following steps.

- a summary tree showing relationships of all genera of Annonaceae was assembled. Details are given below, in the section 'Annonaceae classification'. Nodes that did not receive significant support (parsimony or maximum likelihood bootstrap percentages, Bayesian posterior probabilities) in any of the published studies were resolved according to the topology most frequently inferred in all used publications.

- we defined clade size in terms of number of species, and not number of higher taxa (e.g. number of genera to define the size of tribes) as the former estimate of clade size can be expected to be more stable than the latter, i.e. more robust to changing taxonomic concepts (Hawthorne \& Hughes 2008).

- species numbers for all genera were taken from Annonbase (Rainer \& Chatrou 2006).

- following Haston et al. (2007), nodes of the phylogenetic tree were rotated in such a way that clades with fewer species were placed before clades with more species. This clade size criterion was applied subsequently to all nodes in the tree, starting from the root node (Fig. 1). The names along the tips, reading down from the top, represent the linear sequence.

\section{Annonaceae classification}

Historically, botanists have been reluctant to provide a classification for genera in the magnoliid family Annonaceae. Even though subfamilies and tribes were described by eminent botanists such as Rafinesque (1815), Endlicher (1839), Hooker \& Thomson (1855) and Baillon (1868), these were hardly used by 
Annonaceae workers at the end of the $20^{\text {th }}$ century, just before the breakthrough of phylogenetic methods. The classification most frequently referred to was the one by Fries (1959), who identified informal groups of genera but was reluctant to solidify his arrangement into a formal classification. Based on phylogenetic analyses of almost all genera, Chatrou et al. (2012) revised the infrafamilial classification of the family, and divided the family into four subfamilies and 14 tribes. An addition to the classification by Chatrou et al. (2012) was published by Guo et al. (2017b) with the new tribe Phoenicantheae, necessary to achieve monophyly of infrafamilial taxa belonging to the grade of species-poor lineages basal to tribe Miliuseae. Further detailed phylogenetic studies of specific tribes and genera, or the discovery of new genera of Annonaceae, did not reveal any previously overlooked deeper lineages within the family, and changes in generic circumscription could be accommodated into existing tribes (Chaowasku et al. 2012; Chaowasku et al. 2013; Guo et al. 2014; Xue et al. 2014; Chaowasku et al. 2015; Couvreur et al. 2015; Tang et al. 2015; Thomas et al. 2015; Ortiz-Rodriguez et al. 2016; Ghogue et al. 2017; Guo et al. 2017a; Stull et al. 2017; Pirie et al. 2018). Thus, we have arrived at a point where the classification of Annonaceae, principally based on plastid sequence data, can be considered stable, and can be used to arrange herbarium specimens. Annonaceae currently contain 2430 species (Rainer \& Chatrou 2006, accessed 15th May 2018), classified into 106 genera.

A few decisions, which cannot be derived from the large-scale phylogenetic trees in Chatrou et al. (2012), Chaowasku et al. (2014) and Guo et al. (2017b), need to be justified:

- We consider the generic name Haplostichanthus a synonym of Polyalthia. Xue et al. (2012) reduced nine species of Haplostichanthus into synonymy of Polyalthia, but did not discuss the status of Haplostichanthus gamopetala (Boerl. ex Koord.) Heusden. Given the morphological similarities of this species with other former species of Haplostichanthus (van Heusden 1994a) we consider this species a synonym of Polyalthia gamopetala Boerl. ex Koord., thus removing the name Haplostichanthus from accepted names in Annonaceae taxonomy.

- Thomas et al. (2012) showed that species formerly included in Oncodostigma are nested in Meiogyne, thus validating the classification of some species of Oncodostigma in the latter genus by van Heusden (1994b). The last remaining species of Oncodostigma have recently been sunk into synonymy of Meiogyne (Turner \& Utteridge 2015; Xue et al. 2017), making the further use of the name Oncodostigma unnecessary.
- We have not included the genus Melodorum. The type specimen of the type species Melodorum fruticosum Lour. cannot be distinguished from Uvaria siamensis (Scheff.) L. L. Zhou, Y. C. F. Su \& R. M. K. Saunders. The problem has been that Melodorum fruticosum has widely been misapplied to Sphaerocoryne spp. Guo et al. (2017b) note this as the probable reason that the position of Melodorum was not resolved before.

- For the tribe Malmeeae we based the linear sequence on Chatrou et al. (2012) and Pirie et al. (2006) with one exception. Analysing an alignment of 66 plastid markers, Lopes et al. (2018) inferred the Malmea / Cremastosperma / Pseudoxandra clade as sister to the remaining Malmeeae, instead of the Onychopetalum / Bocageopsis / Unonopsis clade. As these relationships were maximally supported in Bayesian analyses we adopt the result of Lopes et al. (2018).

- the position of Diclinanona was clarified in Erkens et al. (2014), that of Wangia was taken from Guo et al. (2014).

- we consider the genus Winitia (Chaowasku et al. 2013) a synonym of Stelechocarpus (Turner 2016).

\section{Linear sequence of Annonaceae}

Accepted names are listed in bold and synonyms in italics. We listed Unona L.f. and Uva Kuntze as synonyms of Xylopia and Uvaria respectively, as the type specimens of the former two genera have been put into synonymy of the latter two. Note, however, that species previously classified in Unona or Uva can now be found in dozens of genera of Annonaceae.

We considered it beyond the scope of this paper to include details on revisions and other taxonomic information, for which we refer to a recent overviews (e.g. Maas et al. 2011; Erkens et al. 2012) and continuously updated taxonomic data in Annonbase (Rainer \& Chatrou 2006), and the website http://annonaceae.myspecies.info.

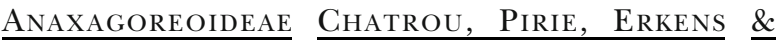 Couvreur \\ $\overline{\text { Anaxagorea }}$ A.St.-Hil. \\ Eburopetalum Becc., Pleuripetalum T. Durand, Rhopalocarpus Teijsm. \& Binn. ex Miq.}

\author{
Ambavioideae Chatrou, Pirie, Erkens \& Couvreur \\ Meiocarpidium Engl. Eं Diels \\ Tetrameranthus R. E. Fr. \\ Cleistopholis Pierre ex Engl. \\ Ambavia Le Thomas \\ Mezzettia Becc.
}

Lonchomera Hook. f. \& Thomson

Lettowianthus Diels

Cyathocalyx Champ. ex Hook. f. E T Thomson 
A

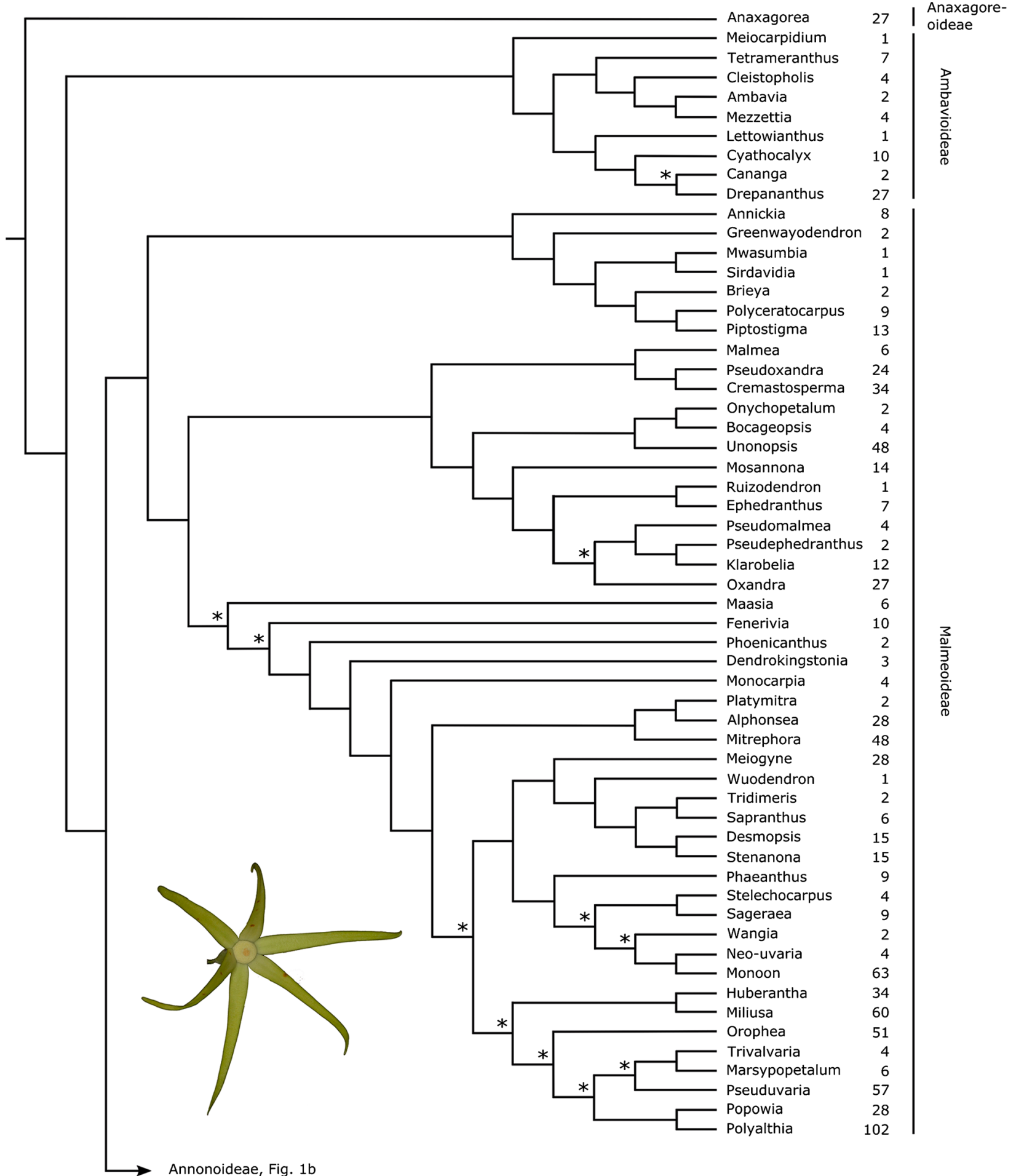

Fig. 1. Summary tree underlying the linear sequence of Annonaceae genera (Fig. 1a: Anaxagoreoideae, Ambavioideae and Malmeoideae; Fig. 1b: Annonoideae). Nodes marked with an asterisk have not received significant support (parsimony or maximum likelihood bootstrap, Bayesian posterior probability) in any publication. The number of species for each genus is indicated. Inset pictures show flowers of Fenerivia capuronii (Cavaco \& Keraudren) R. M. K. Saunders (Fig. 1a) and Guatteria aeruginosa Standl. (Fig. 1b). PHOTOS: L. W. CHATROU. 
B

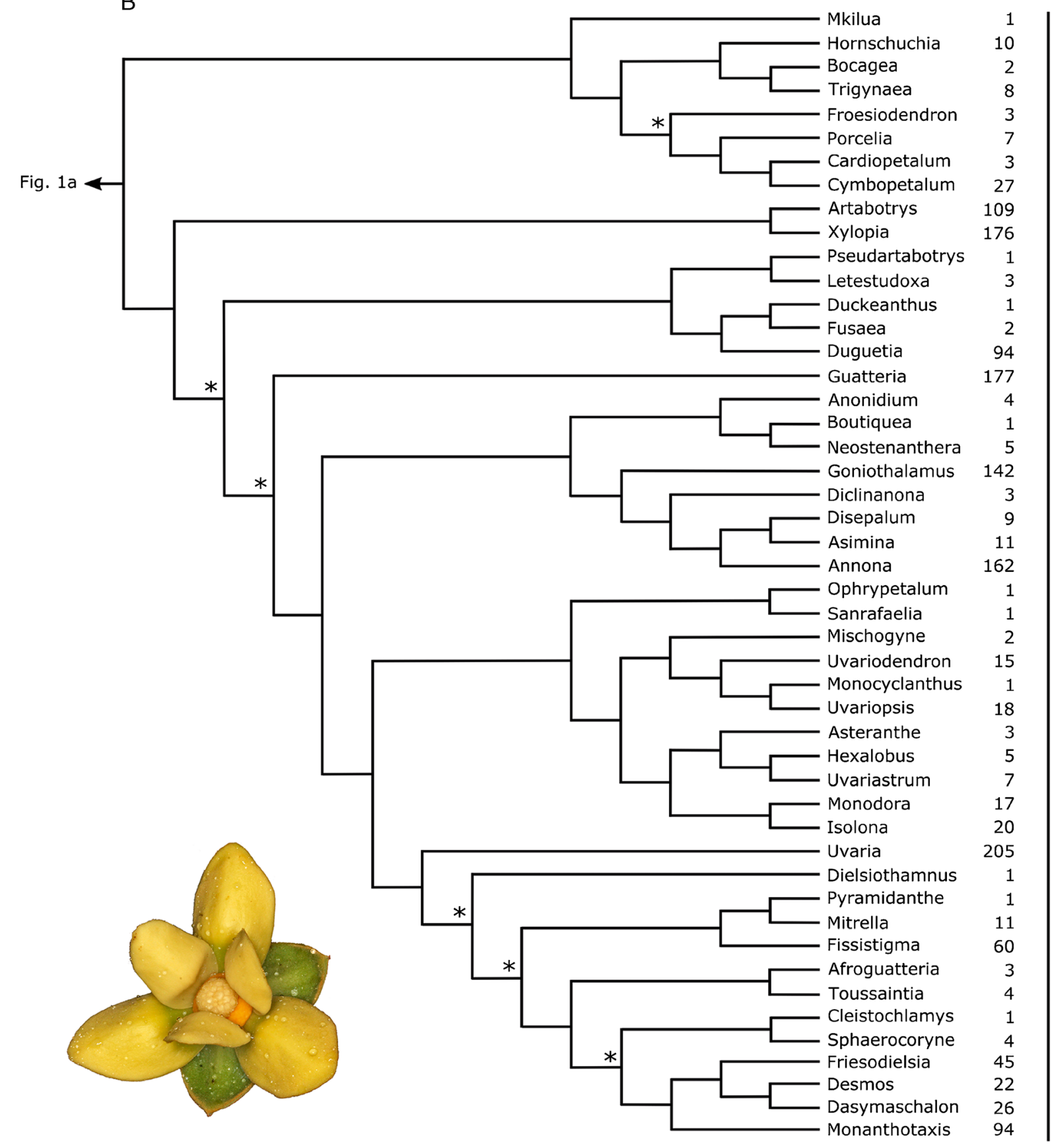

Fig. 1. (continued)

Cananga (Dunal) Hook. f. E Thomson

Canangium Baill. ex King, Fitzgeraldia F. Muell.

Drepananthus Maingay ex Hook. $f$.

Malmeoideae Chatrou, Pirie, Erkens \& Couvreur Piptostigmateae Chatrou \& R. M. K. Saunders

Annickia Setten E Maas

Enantia Oliv.

Greenwayodendron $\operatorname{Verd}$.
Mwasumbia Couvreur $\mathcal{E} \mathcal{F}^{2}$ D. M. Johnson

Sirdavidia Couvreur E Sauquet

Brieya De Wild.

Polyceratocarpus Engl. E Diels

Alphonseopsis Baker f., Dielsina Kuntze

Piptostigma Oliv.

Malmeeae Chatrou \& R. M. K. Saunders Malmea R. E. Fr. 
Pseudoxandra $R$. E. Fr.

Cremastosperma $R$. E. Fr.

Onychopetalum R. E. Fr.

Bocageopsis R. E. Fr.

Unonopsis R. E. Fr.

Mosannona Chatrou

Ruizodendron $R$. E. Fr.

Ephedranthus S. Moore

Pseudomalmea Chatrou

Pseudephedranthus Aristeg.

Klarobelia Chatrou

Oxandra A. Rich.

Maasieae Chatrou \& R. M. K. Saunders

Maasia Mols, Kessler E Rogstad

Fenerivieae Chatrou \& R. M. K. Saunders

Fenerivia Diels

Phoenicantheae X. Guo \& R. M. K. Saunders

Phoenicanthus Alston

Dendrokingstonieae Chatrou \& R. M. K. Saunders

Dendrokingstonia Rauschert

Kingstonia Hook. f. \& Thomson

Monocarpieae Chatrou \& R. M. K. Saunders

Monocarpia Miq.

Miliuseae Hook. f. \& Thomson

Platymitra Boerl.

Macanea Blanco

Alphonsea Hook. $f$. E Thomson

Mitrephora (Blume) Hook. f. E Thomson

Kinginda Kuntze

Meiogyne Miq.

Ancana F. Muell., Ararocarpus Scheff., Chieniodendron

Tsiang \& P. T. Li, Fitzalania F. Muell., Guamia

Merr., Oncodostigma Diels, Polyaulax Backer

Wuodendron B. Xue, Y. H. Tan E Chaowasku

Tridimeris Baill.

Sapranthus Seem.

Desmopsis Saff.

Reedrollinsia J. W. Walker

Stenanona Standl.

Phaeanthus Hook. f. E Thomson

Stelechocarpus Hook. f. E Thomson

Winitia Chaowasku

Sageraea Dalzell

Wangia X. Guo Ẽ R. M. K. Saunders
Neouvaria Airy Shaw

Monoon Miq.

Cleistopetalum H. Okada, Enicosanthum Becc., Griffithia Maingay ex King, Griffithianthus Merr., Marcuccia Becc., Woodiella Merr., Woodiellantha Rauschert

Huberantha Chaowasku

Hubera Chaowasku

Miliusa Lesch. ex A. DC. Hyalostemma Wall., Saccopetalum Benn.

Orophea Blume Mezzettiopsis Ridl.

Trivalvaria (Miq.) Miq.

Marsypopetalum Scheff.

Pseuduvaria Miq. Craibella R. M. K. Saunders, Y. C. F. Su \& Chalermglin, Oreomitra Diels, Petalolophus K. Schum.

Popowia Endl.

Polyalthia Blume

Haplostichanthus F. Muell., Papualthia Diels, Sphaerothalamus Hook. f.

ANNONOIDEAE RAF.

Bocageeae Endl.

Mkilua $\operatorname{Verd} c$.

Hornschuchia Nees Mosenodendron R. E. Fr.

Bocagea A. St.-Hil.

Trigynaea $S$ chltdl.

Froesiodendron R. E. Fr.

Porcelia Ruiz E Pav.

Cardiopetalum Schltdl. Stormia S. Moore

Cymbopetalum Benth.

Xylopieae Endl.

Artabotrys $R$. Br. Ropalopetalum Griff.

Xylopia $L$.

Coelocline A. DC., Habzelia A. DC., Krockeria Necker, Parabotrys Müll., Parartabotrys Miq., Patonia Wight, Pseudannona Saff., Unona L. f., Waria Aubl., Xylopiastrum Roberty, Xylopicron Adans., Xylopicrum P. Browne

Duguetieae Chatrou \& R. M. K. Saunders

Pseudartabotrys Pellegr.

Letestudoxa Pellegr.

Duckeanthus R. E. Fr.

Fusaea (Baill.) Saff.

Duguetia A. St.-Hil.

Aberemoa Aubl., Alcmene Urb., Geanthemum (R. E. Fr.) Saff., Pachypodanthium Engl. \& Diels 
Guatterieae Hook. f. \& Thomson

Guatteria Ruiz E Pav.

Guatteriella R. E. Fr., Guatteriopsis R. E. Fr., Heteropetalum Benth.

Annoneae Endl.

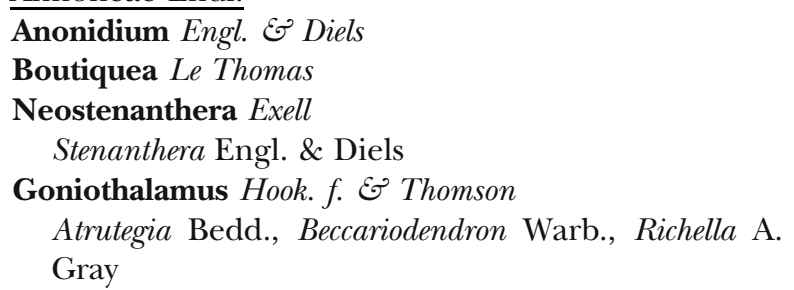

Diclinanona Diels

Disepalum Hook. f. Enicosanthellum Bân

Asimina Adans.

Deeringothamnus Small, Orchidocarpum Michx., Pityothamnus Small

Annona $L$.

Guanabanus Mill., Raimondia Saff., Rollinia A. St.Hil., Rolliniopsis Saff.

Monodoreae Baill.

Ophrypetalum Diels

Sanrafaelia Verdc.

Mischogyne Exell

Uvariodendron (Engl. Eo Diels) R. E. Fr.

Monocyclanthus Keay

Uvariopsis Engl.

Dennettia Baker f., Tetrastemma Diels, Thonnera De Wild.

Asteranthe Engl. Ẽ Diels

Asteranthopsis Kuntze

Hexalobus A. DC.

Uvariastrum Engl.

Monodora Dunal

Isolona Engl.

Uvarieae Hook. f. \& Thomson

Uvaria $L$.

Anomianthus Zoll., Armenteria Thouars ex Baill., Balonga Le Thomas, Cyathostemma Griff., Dasoclema J. Sinclair, Ellipeia Hook. f. \& Thomson, Ellipeiopsis R. E. Fr., Marenteria Thouars, Melodorum Lour., Narum Adans., Naruma Raf., Pyragma Noronha, Rauwenhoffia Scheff., Tetrapetalum Miq., Uva Kuntze, Uvariella Ridl.

Dielsiothamnus R. E. Fr.

Pyramidanthe Miq.

Mitrella Miq.

Fissistigma Griff.

Afroguatteria Boutique

\author{
Toussaintia Boutique \\ Cleistochlamys Oliv. \\ Sphaerocoryne (Boerl.) Scheff. ex Ridl. \\ Friesodielsia Steenis \\ Oxymitra (Blume) Hook. f. \& Thomson, \\ Schefferomitra Diels \\ Desmos Lour. \\ Dasymaschalon (Hook. f. Eं Thomson) Dalla Torre $\mathcal{E}$ \\ Harms \\ Pelticalyx Griff. \\ Monanthotaxis Baill. \\ Atopostema Boutique, Clathrospermum Planch. ex \\ Benth., Enneastemon Exell, Exellia Boutique, \\ Gilbertiella Boutique
}

\section{Acknowledgements}

Financial support from the Bentham-Moxon Trust is gratefully acknowledged. We thank Thomas Couvreur and Michael Pirie for constructive criticism.

Open Access This article is distributed under the terms of the Creative Commons Attribution 4.0 International License (http://creativecommons.org/ licenses/by/4.0/), which permits unrestricted use, distribution, and reproduction in any medium, provided you give appropriate credit to the original author(s) and the source, provide a link to the Creative Commons license, and indicate if changes were made.

\section{References}

APG I. (1998). An ordinal classification for the families of flowering plants. Ann. Missouri Bot. Gard. 85: $531-553$.

APG II. (2003). An update of the Angiosperm Phylogeny Group classification for the orders and families of flowering plants: APG II. Bot. J. Linn. Soc. 141: $399-436$.

APG III. (2009). An update of the Angiosperm Phylogeny Group classification for the orders and families of flowering plants: APG III. Bot. J. Linn. Soc. 161: 105 - 121.

APG IV. (2016). An update of the Angiosperm Phylogeny Group classification for the orders and families of flowering plants: APG IV. Bot. J. Linn. Soc. 181: $1-20$.

Baillon, H. E. (1868). Anonacées. L. Hachette et Cie., Paris.

Bakker, F. T., Lei, D., Yu, J., Mohammadin, S., Wei, Z., van de Kerke, S., Gravendeel, B., Nieuwenhuis, M., Staats, M., Alquezar-Planas, D. E. \& Holmer, R. (2016). Herbarium genomics: plastome sequence assembly from a range of herbarium specimens 
using an Iterative Organelle Genome Assembly pipeline. Biol. J. Linn. Soc. 117: 33 - 43.

Bentham, G. \& Hooker, J. D. (1862 - 1883). Genera Plantarum. A. Black, London.

Bone, R. E., Cribb, P. J. \& Buerki, S. (2015). Phylogenetics of Eulophiinae (Orchidaceae: Epidendroideae): evolutionary patterns and implications for generic delimitation. Bot. J. Linn. Soc. 179: 43 - 56.

Burger, W. C. (2004). Up with alphabetically arranged herbaria (and with floristic listings too for that matter). Plant Sci Bull 50: 7 - 9.

Cardoso, D., Särkinen, T., Alexander, S., Amorim, A. M., Bittrich, V., Celis, M., Daly, D. C., Fiaschi, P., Funk, V. A., Giacomin, L. L., Goldenberg, R., Heiden, G., Iganci, J., Kelloff, C. L., Knapp, S., Cavalcante de Lima, H., Machado, A. F. P., dos Santos, R. M., Mello-Silva, R., Michelangeli, F. A., Mitchell, J., Moonlight, P., de Moraes, P. L. R., Mori, S. A., Nunes, T. S., Pennington, T. D., Pirani, J. R., Prance, G. T., de Queiroz, L. P., Rapini, A., Riina, R., Rincon, C. A. V., Roque, N., Shimizu, G., Sobral, M., Stehmann, J. R., Stevens, W. D., Taylor, C. M., Trovó, M., van den Berg, C., van der Werff, H., Viana, P. L., Zartman, C. E. \& Forzza, R. C. (2017). Amazon plant diversity revealed by a taxonomically verified species list. Proc. Natl. Acad. Sci. USA 114: 10695 - 10700.

Chacón, J., Luebert, F., Hilger, H. H., Ovchinnikova, S., Selvi, F., Cecchi, L., Guilliams, C. M., HasenstabLehman, K., Sutorý, K., Simpson, M. G. \& Weigend, M. (2016). The borage family (Boraginaceae s.str.): A revised infrafamilial classification based on new phylogenetic evidence, with emphasis on the placement of some enigmatic genera. Taxon 65: $523-546$.

Chaowasku, T., Johnson, D. M., van der Ham, R. W. J. M. \& Chatrou, L. W. (2012). Characterization of Hubera (Annonaceae), a new genus segregated from Polyalthia and allied to Miliusa. Phytotaxa 69: $33-56$.

\& ____ (2015). Huberantha, a replacement name for Hubera (Annonaceae: Malmeoideae: Miliuseae). Kew Bull. 70: 23.

, Thomas, D. C., van der Ham, R. W. J. M., Smets, E. F., Mols, J. B. \& Chatrou, L. W. (2014). A plastid DNA phylogeny of tribe Miliuseae: Insights into relationships and character evolution in one of the most recalcitrant major clades of Annonaceae. Amer. J. Bot. 101: 691 - 709.

, van der Ham, R. W. J. M. \& Chatrou, L. W. (2013). Integrative systematics supports the establishment of Winitia, a new genus of Annonaceae (Malmeoideae, Miliuseae) allied to Stelechocarpus and Sageraea. Syst. Biodivers. 11: 195 - 207.

Chatrou, L. W., Pirie, M. D., Erkens, R. H. J., Couvreur, T. L. P., Neubig, K. M., Abbott, J. R., Mols, J. B., Maas, J. W., Saunders, R. M. K. \& Chase,
M. W. (2012). A new subfamilial and tribal classification of the pantropical flowering plant family Annonaceae informed by molecular phylogenetics. Bot. J. Linn. Soc. 169: 5 - 40.

Christenhusz, M. J. M., Reveal, J. L., Farjon, A., Gardner, M. F., Mill, R. R. \& Chase, M. W. (2011a). A new classification and linear sequence of extant gymnosperms. Phytotaxa 19: $55-70$.

, Zhang, X.-C. \& Schneider, H. (2011b). A linear sequence of extant families and genera of lycophytes and ferns. Phytotaxa 19: 7 - 54 .

Claudel, C., Buerki, S., Chatrou, L. W., Antonelli, A., Alvarez, N. \& Hetterscheid, W. (2017). Large-scale phylogenetic analysis of Amorphophallus (Araceae) derived from nuclear and plastid sequences reveals new subgeneric delineation. Bot. J. Linn. Soc. 184: $32-45$.

Couvreur, T. L. P., Niangadouma, R., Sonké, B. \& Sauquet, H. (2015). Sirdavidia, an extraordinary new genus of Annonaceae from Gabon. PhytoKeys 46: $1-19$.

De Faria, A. D., Pirani, J. R., Ribeiro, J. E. L. D. S., Nylinder, S., Terra-Araujo, M. H., Vieira, P. P. \& Swenson, U. (2017). Towards a natural classification of Sapotaceae subfamily Chrysophylloideae in the Neotropics. Bot. J. Linn. Soc. 185: $27-55$.

Endlicher, S. (1839). Genera plantarum secundum ordines naturales disposita. Fr. Beck Universitatis Bibliopolam, Vienna.

Engler, A. \& Gilg, E. (1924). Syllabus der Pflanzenfamilien. Gebrüder Borntraeger Verlag, Berlin.

Erkens, R. H. J., Chatrou, L. W., Chaowasku, T., Westra, L. Y. T., Maas, J. W. \& Maas, P. J. M. (2014). A decade of uncertainty: Resolving the phylogenetic position of Diclinanona (Annonaceae), including taxonomic notes and a key to the species. Taxon 63: 1244 - 1252.

Mennega, E. A. \& Westra, L. Y. T. (2012). A concise bibliographic overview of Annonaceae. Bot. J. Linn. Soc. 169: 41 - 73.

Fries, R. E. (1959). Annonaceae. In: A. Engler \& K. Prantl (eds), Die natürlichen Pflanzenfamilien, ed. 2 ed, pp. 1 - 171. Duncker \& Humblot, Berlin.

Funk, V. A. (2003). Down with alphabetically arranged herbaria (and alphabetically arranged floras too for that matter). Plant Sci Bull 49: 131 - 132.

Ghogue, J.-P., Sonké, B. \& Couvreur, T. L. P. (2017). Taxonomic revision of the African genera Brieya and Piptostigma (Annonaceae). Plant Ecol. Evol. 150: $173-216$.

Guo, X., Hoekstra, P. H., Tang, C. C., Thomas, D. C., Wieringa, J. J., Chatrou, L. W. \& Saunders, R. M. K. (2017a). Cutting up the climbers: Evidence for extensive polyphyly in Friesodielsia (Annonaceae) necessitates generic realignment across the tribe Uvarieae. Taxon 66: 3 - 19. 
Tang, C. C., Thomas, D. C., Couvreur, T. L. P. \& Saunders, R. M. K. (2017b). A mega-phylogeny of the Annonaceae: taxonomic placement of five enigmatic genera and support for a new tribe, Phoenicantheae. Sci. Rep. 7: 7323.

,Wang, J., Xue, B., Thomas, D. C., Su, Y. C. F., Tan, Y.-H. \& Saunders, R. M. K. (2014). Reassessing the taxonomic status of two enigmatic Desmos species (Annonaceae): Morphological and molecular phylogenetic support for a new genus, Wangia. J. Syst. Evol. 52: 1 - 15.

Hart, M. L., Forrest, L. L., Nicholls, J. A. \& Kidner, C. A. (2016). Retrieval of hundreds of nuclear loci from herbarium specimens. Taxon 65: 1081 - 1092.

Haston, E., Richardson, J. E., Stevens, P. F., Chase, M. W. \& Harris, D. J. (2007). A linear sequence of Angiosperm Phylogeny Group II families. Taxon 56: 7. \& (2009). The Linear Angiosperm Phylogeny Group (LAPG) III: a linear sequence of the families in APG III. Bot. J. Linn. Soc. 161: 128 - 131.

Hawthorne, W. D. \& Hughes, C. E. (2008). Optimising linear taxon sequences derived from phylogenetic trees - a reply to Haston \& al. Taxon 57: 698 - 704.

Henry, A. G., Brooks, A. S. \& Piperno, D. R. (2011). Microfossils in calculus demonstrate consumption of plants and cooked foods in Neanderthal diets (Shanidar III, Iraq; Spy I and II, Belgium). Proc. Natl. Acad. Sci. USA 108: 486 491.

Hoekstra, P. H., Wieringa, J. J., Smets, E., Brandão, R. D., Lopes, J. C., Erkens, R. H. J. \& Chatrou, L. W. (2017). Correlated evolutionary rates across genomic compartments in Annonaceae. Molec. Phylogenet. Evol. 114: 63 - 72.

Hooker, J. D. \& Thomson, T. (1855). Flora Indica, pp. 86 - 153. W. Pamplin, London.

Jussieu, A. L., de. (1789). Genera plantarum. Herissant, Paris. Le Bras, G., Pignal, M., Jeanson, M. L., Muller, S., Aupic, C., Carré, B., Flament, G., Gaudeul, M., Gonçalves, C., Invernón, V. R., Jabbour, F., Lerat, E., Lowry, P. P., Offroy, B., Pimparé, E. P., Poncy, O., Rouhan, G. \& Haevermans, T. (2017). The French Muséum national d'histoire naturelle vascular plant herbarium collection dataset. Sci. Data 4: 170016.

Lewis, G. P., Schrire, B. D., Mackinder, B. A., Rico, L. \& Clark, R. (2013). A 2013 linear sequence of legume genera set in a phylogenetic context - a tool for collections management and taxon sampling. S. Afr. J. Bot. 89: $76-84$.

Linnaeus, C. (1753). Species plantarum. Laurentius Salvius, Stockholm.

Lopes, J. C., Chatrou, L. W., Mello-Silva, R., Rudall, P. J. \& Sajo, M. G. (2018). Phylogenomics and evolution of floral traits in the Neotropical tribe
Malmeeae (Annonaceae). Molec. Phylogenet. Evol. 118: 379 - 391 .

Maas, P. J. M., Westra, L. Y. T., Rainer, H., Lobão, A. Q. \& Erkens, R. H. J. (2011). An updated index to genera, species, and infraspecific taxa of Neotropical Annonaceae. Nord. J. Bot. 29: 257 - 356.

Marshall, C. A. M., Wieringa, J. J. \& Hawthorne, W. D. (2016). Bioquality hotspots in the tropical African flora. Curr. Biol. 26: $3214-3219$.

Nadel, D., Danin, A., Power, R. C., Rosen, A. M., Bocquentin, F., Tsatskin, A., Rosenberg, D., Yeshurun, R., Weissbrod, L., Rebollo, N. R., Barzilai, O. \& Boaretto, E. (2013). Earliest floral grave lining from 13,700 - 11,700-y-old Natufian burials at Raqefet Cave, Mt. Carmel, Israel. Proc. Natl. Acad. Sci. USA 110: 11774 - 11778.

Ortiz-Rodriguez, A. E., Ruiz-Sanchez, E. \& Ornelas, J. F. (2016). Phylogenetic relationships among members of the Neotropical clade of Miliuseae (Annonaceae): generic non-monophyly of Desmopsis and Stenanona. Syst. Bot. 41: 815 - 822.

Pirie, M. D., Chatrou, L. W., Mols, J. B., Erkens, R. H. J. \& Oosterhof, J. (2006). Andean-centred' genera in the short-branch clade of Annonaceae: testing biogeographical hypotheses using phylogeny reconstruction and molecular dating. J. Biogeogr. 33: 31 - 46.

Maas, P. J. M., Wilschut, R. A., Melchers-Sharrott, H. \& Chatrou, L. W. (2018). Parallel diversifications of Cremastosperma and Mosannona (Annonaceae), tropical rainforest trees tracking Neogene upheaval of South America. Roy. Soc. Open Sci. 5: 171561.

Power, R. C., Rosen, A. M. \& Nadel, D. (2014). The economic and ritual utilization of plants at the Raqefet Cave Natufian site: The evidence from phytoliths. J. Anthropol. Archaeol. 33: 49 - 65.

Rafinesque, C. S. (1815). Analyse de la nature. Aux dépens de l'auteur, Palermo.

Rainer, H. \& Chatrou, L. W. (2006). AnnonBase: World species list of Annonaceae - version 1.1, 12 Oct 2006 [and updated continuously]. http://www.sp2000.org/ and http://www.annonaceae.org/.

Schneider, J. V., Bissiengou, P., Amaral, M. C. E., Tahir, A., Fay, M. F., Thines, M., Sosef, M. S. M., Zizka, G. \& Chatrou, L. W. (2014). Phylogenetics, ancestral state reconstruction, and a new infrafamilial classification of the pantropical Ochnaceae (Medusagynaceae, Ochnaceae s.str., Quiinaceae) based on five DNA regions. Molec. Phylogenet. Evol. 78: 199 - 214.

Simões, A. R. \& Staples, G. (2017). Dissolution of Convolvulaceae tribe Merremieae and a new classification of the constituent genera. Bot. J. Linn. Soc. 183: $561-586$.

Sosef, M. S. M., Dauby, G., Blach-Overgaard, A., van der Burgt, X., Catarino, L., Damen, T., Deblauwe, V., Dessein, S., Dransfield, J., Droissart, V., Duarte, M. C., Engledow, H., Fadeur, G., Figueira, R., Gereau, R. E., Hardy, O. J., Harris, D. J., de Heij, J., Janssens, S., 
Klomberg, Y., Ley, A. C., Mackinder, B. A., Meerts, P., van de Poel, J. L., Sonké, B., Stévart, T., Stoffelen, P., Svenning, J.-C., Sepulchre, P., Zaiss, R., Wieringa, J. J. \& Couvreur, T. L. P. (2017). Exploring the floristic diversity of tropical Africa. BMC Biol. 15: 15.

Stull, G. W., Johnson, D. M., Murray, N. A., Couvreur, T. L. P., Reeger, J. E. \& Roy, C. M. (2017). Plastid and seed morphology data support a revised infrageneric classification and an African origin of the pantropical genus Xylopia (Annonaceae). Syst. Bot. 42: 211 - 225.

Tang, C. C., Thomas, D. C. \& Saunders, R. M. K. (2015). Molecular phylogenetics of the species-rich angiosperm genus Goniothalamus (Annonaceae) inferred from nine chloroplast DNA regions: synapomorphies and putative correlated evolutionary changes in fruit and seed morphology. Molec. Phylogenet. Evol. 92: 124 - 139.

Thomas, D. C., Chatrou, L. W., Stull, G. W., Johnson, D. M., Harris, D. J., Thongpairoj, U. \& Saunders, R. M. K. (2015). The historical origins of palaeotropical intercontinental disjunctions in the pantropical flowering plant family Annonaceae. Perspect. Plant Ecol. Evol. Syst. 17: 1 - 16.

, Surveswaran, S., Xue, B., Sankowsky, G., Mols, J. B., Keßler, P. J. A. \& Saunders, R. M. K. (2012). Molecular phylogenetics and historical biogeography of the Meiogyne-Fitzalania clade (Annonaceae): generic paraphyly and late Miocene-Pliocene diversification in Australasia and the Pacific. Taxon 61: 559 - 575.

Trias-Blasi, A., Baker, W. J., Haigh, A. L., Simpson, D. A., Weber, O. \& Wilkin, P. (2015). A genus-level phylogenetic linear sequence of monocots. Taxon 64: $552-581$.

Turner, I. M. (2016). Notes on the Annonaceae of the Malay Peninsula. Gard. Bull. Singapore 68: 65 - 69. (in press). Annonaceae of the Asia-Pacific region: names, types and distributions. Gard. Bull. Singapore. \& Utteridge, T. M. A. (2015). A new species and a new combination in Meiogyne (Annonaceae) of New Guinea. Contributions to the Flora of Mt Jaya, XXI. Kew Bull. 70: 27.

van Heusden, E. C. H. (1994a). Revision of Haplostichanthus (Annonaceae). Blumea 39: 215 - 234. (1994b). Revision of Meiogyne (Annonaceae). Blumea 38: 487 - 511.

Wearn, J. A., Chase, M. W., Mabberley, D. J. \& Couch, C. (2013). Utilizing a phylogenetic plant classification for systematic arrangements in botanic gardens and herbaria. Bot. J. Linn. Soc. 172: 127 - 141 .

Willis, C. G., Ellwood, E. R., Primack, R. B., Davis, C. C., Pearson, K. D., Gallinat, A. S., Yost, J. M., Nelson, G., Mazer, S. J., Rossington, N. L., Sparks, T. H. \& Soltis, P. S. (2017). Old plants, new tricks: phenological research using herbarium specimens. Trends Ecol. Evol. 32: 531 - 546.

Xue, B., Liu, M.-F. \& Saunders, R. M. K. (2017). The nomenclatural demise of Oncodostigma (Annonaceae): the remaining species transferred to Meiogyne. Phytotaxa 309: $297-298$.

Su, Y. C. F., Thomas, D. C. \& Saunders, R. M. K. (2012). Pruning the polyphyletic genus Polyalthia (Annonaceae) and resurrecting the genus Monoon. Taxon 61: 1021 - 1039.

Thomas, D. C., Chaowasku, T., Johnson, D. M. \& Saunders, R. M. K. (2014). Molecular phylogenetic support for the taxonomic merger of Fitzalania and Meiogyne (Annonaceae): new nomenclatural combinations under the conserved name Meiogyne. Syst. Bot. 39: 396 - 404. 